\title{
Evolution of the processed tomato sector in portugal and Spain: comparative analysis
}

\author{
Maria de Fátima Martins Lorena de Oliveira ${ }^{1 *}$, Mariano Suárez de Cepeda ${ }^{2}$, Rodolfo Bernabéu ${ }^{3}$ \\ ${ }^{1}$ Instituto Politécnico de Coimbra, Escola Superior Agrária, Bencanta, 3045-601 Coimbra, Portugal, ${ }^{2}$ Universidad de Castilla-La Mancha, \\ Escuela Técnica Superior de Ingenieros Agrónomos y de Montes, Campus Universitario s/n 02071 Albacete, Spain, ${ }^{2}$ Universidad de \\ Castilla-La Mancha, Escuela Técnica Superior de Ingenieros Agrónomos y de Montes, Campus Universitario s/n 02071 Albacete, Spain
}

\section{A B S T R A C T}

\begin{abstract}
World production of processed tomato has shifted from the traditional producing countries to others that were previously importers, thereby increasing competition between companies and slowing down agro-industrial and trade growth. Portugal, one of the world's leading producers of processed tomato has not been immune to this trend, as witnessed by its decline in international competitiveness over the period from 1981 to 2013. The aim of the present study is thus twofold. On the one hand, using various standardized indicators, the determinants of the business competitiveness of processed tomato are analyzed, and, on the other, we perform a comparative analysis between Spain and Portugal. The standardized indicators used in this study are the Revealed Comparative Advantage (RCA), the Revealed Symmetric Comparative Advantage (RSCA) and the Grubel-Lloyd indicator (GL). The results show that price continues to be the primary determinant in processed tomato exports. Specifically, while trade in tomato paste in Portugal is inter-industry, trade in other tomato products is horizontal intra-industry in nature. In conclusion, the relationship between agro-industrial development and technological innovation in Portugal and Spain is key to reducing costs as a strategy to bring competitive and sustainable products to the market.
\end{abstract}

Keywords: Agri-food marketing; Competitiveness; Processing; Production; Tomato

\section{INTRODUCTION}

The Food and Beverages sector (F\&B) is considered a strategic industry in improving the growth of the Portuguese economy. Table 1 shows the trade balance of the $\mathrm{F} \& \mathrm{~B}$, which demonstrates the importance of the tomato industry in reducing the trade deficit.

Between 2011 and 2013, on average, Portuguese tomato paste represented $96 \%$ of the total exports of processed tomato products and peeled tomatoes accounted for around 4\%. There was a significant increase in exports of this product compared to the period between 1992 and 2007, in which it accounted for $2 \%$ of exports. Tomato juice represented $0.05 \%$ of the total exported tomato products and this value has remained constant (FAOSTAT, several years).

In 2014 (16) tri-annual average values, Portugal was the $7^{\text {th }}$ world producer of raw tomatoes for processing with $4 \%$ of world production and the $3^{\text {rd }}$ producer within the European Union (EU), with 14\% of the EU production.
Portugal is the $5^{\text {th }}$ largest world tomato pasta exporter with $7 \%$ and the $3^{\text {rd }}$ EU exporter with around $15 \%$ of EU exports. Spain is the $4^{\text {th }}$ largest producer of raw tomatoes for processing ( $7 \%$ of world production and $21 \%$ of EU production). Regarding tomato paste exports, Spain is the world's $4^{\text {th }}$ largest tomato paste exporter $(9 \%$ of world exports) and $2^{\text {nd }}$ largest exporter in the EU (21\% of EU tomato paste exports). Italy is the world's $3^{\text {rd }}$ largest producer of raw tomatoes for processing (13\% of production) and the world's $2^{\text {nd }}$ largest tomato paste exporter with $23 \%$ and the EU's largest exporter (56\% of EU exports) (WTPC and FAOSTAT, several years).

In 2014/16 (average tri-annual values) the three largest worldwide tomato paste importers were: Germany, with 9\% of total imports, Italy and Japan with 5\% (FAOSTAT, several years). Between 2011 and 2013, the largest Portuguese tomato product importers were the United Kingdom with $27 \%$ of Portuguese exports, followed by Japan (15\%) and Spain with 13\% (AICEP, several years). 
The apparent per capita consumption of processed tomato products differs from source to source. According to the Tomato News website (several years), the per capita consumption rose from $4.0 \mathrm{~kg} /$ year in 1996 to around $6.1 \mathrm{~kg} /$ year in 2015. The countries with the highest per capita consumption are the United Arab Emirates with $32.1 \mathrm{~kg} /$ year, followed by Australia and New Zealand with $22.9 \mathrm{~kg} /$ year, and Iraq with $21.9 \mathrm{~kg} /$ year.

Fig. 1 shows a significant annual average growth rate of consumption in non-processed tomato markets, with a notable increase in consumption in East and West Africa. Consumption of processed tomato products has become globalized and about $75 \%$ of this consumption takes place outside traditional production regions (Tomato News, 2014).

Between 1989(93) and 2012(16), world tomato production (fresh consumption and industry) showed an Average Annual Growth Rate (AAGR) of 43\% (average five-year values). In the EU, the AAGR was much lower $(0.3 \%)$. The relationship between tomato production for fresh consumption and for processing is relevant to the present study since both productions are competing in terms of production areas. Worldwide, the production of fresh tomato has increased in importance compared to tomato production for processing, while in the EU the trend is reversed (Fig. 2). In the case of tomatoes for processing, between 1989(93) and 2012(16), world production grew with an AAGR of $2.3 \%$, while in the EU this rate was $1.3 \%$.
There is a clear reduction in the importance of tomato production in the EU in relation to world production (Fig. 2), both for fresh consumption and for processing. This is due to investments in California, China and North Africa. The area of production in North Africa decreased between 2000 (04) and 2010 (14) by 2\%, but in the same period production increased by $17 \%$, demonstrating a commitment to improving technology and productivity. Iran has become a potential producer of tomatoes for industry, with $5 \%$ of world production of tomatoes for industry in 2011-13, making it the $6^{\text {th }}$ largest producer of tomatoes for industry. However, from 2015 to 2017 its importance in world production value decreased to $3 \%$. Despite its potential, Iran presents a certain instability in tomato production for industry, and more time is needed to understand its role in the industry.

Portuguese production of tomatoes for processing increased from 732 thousand tons in 1993 (95) to 1,285 thousand tons in 2013 (15), representing a $2.0 \%$ higher annual average growth rate than the growth in world tomato production, which was $2.5 \%$ per year over the same period (WTPC, several years). The Alentejo region accounts for $83 \%$ of national production, followed by the Lisbon and Tagus Valley region with 17\% (INE, 2016). In Spain, this growth was 4\% (WTPC, several years). Extremadura accounts for $72 \%$ of production in Spain, followed by Andalusia with 17\% (Llerena, 2015).

The work by Bunte and Roza (2007) on subsidy reduction and decoupling predicted that changes in the Common

Table 1: Trade Balance of the Food, Agriculture and Beverage Industry (F\&B) and the Tomato Industry in thousands of Euros (P. constants, GDP deflator: 2011) in Portugal

\begin{tabular}{lccccccccccccccc} 
Years & 2001 & 2002 & 2003 & 2004 & 2005 & 2006 & 2007 & 2008 & 2009 & 2010 & 2011 & 2012 & 2013 & 2014 & 2015 \\
\hline F\&B & - & - & - & - & - & - & - & - & - & - & - & - & - & - & - \\
& 4,528 & 4,115 & 3,899 & 4,008 & 3,846 & 3,958 & 4,294 & 4,438 & 3,964 & 4,069 & 4,200 & 3,724 & 3,648 & 3,137 & 3,244 \\
Tomato & 91 & 105 & 103 & 87 & 81 & 92 & 101 & 114 & 142 & 131 & 143 & 151 & 176 & 172 & 187 \\
processed & & & & & & & & & & & & &
\end{tabular}

Source: Prepared from the data of the Agência para o Investimento e Comércio Externo de Portuga (AICEP, 2017).

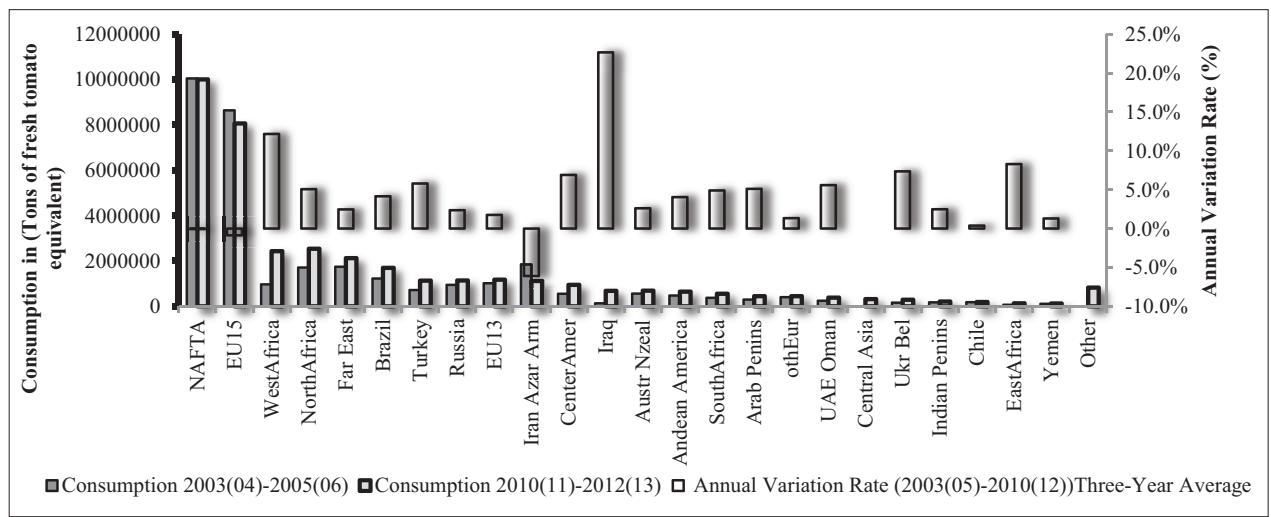

Fig 1. Consumption of processed tomatoes according to raw tomato regions (2003 and 2012) (t).

Source. Prepared from the data elaborated by the authors, based on Tomato News (2014). 
Agricultural Policy would reduce tomato production for processing by $15 \%$ in Portugal and 35\% in Italy. This study concluded that the European Mediterranean countries would have a comparative advantage for fruit and vegetable production instead of arable crops, in which tomatoes for processing would be included. However, between 2012 and 2015, Italy, Spain and Portugal increased their tomato production for processing by about $20 \%, 56 \%$ and $39 \%$ respectively.

Between 2012 and 2015, the horticultural area in Portugal increased by $3 \%$ and production increased by $9 \%$. The area of fresh fruits and small berries increased by $47 \%$ and production rose by $32 \%$, while the area of tomato production for processing increased by 39\% (Agricultural Statistics, several years). In the Spanish region of Extremadura, between 2012 and 2014, the tomato area for industry increased by $20 \%$ and production rose by $31 \%$.

Table 2 summarizes the evolution of the agricultural sector for tomatoes for industry in Portugal. Despite the evident reduction in the number of farmers, area and productivity increased following the structuring period. This process also occurred in Spain. These results show increased concentration of the production of raw material, following a similar strategy of concentration in the tomato processing industry (Oliveira, 2006).

This work aims to analyze the competitiveness of tomatoes for processing in the Portuguese and Spanish industries, using a set of indicators of international competitiveness from 1981 to 2013 to carry out a tri-annual analysis. The factors that might influence tomato paste exports are analyzed and a comparison with the Spanish tomato industry is conducted.

\section{MATERIAL AND METHODS}

The Revealed Comparative Advantage (RCA) is one of the most commonly used indicators to study the competitiveness of a sector in a region. The RCA is often calculated by the share in the country's exports of the product to be analyzed relative to its share in trade and can be defined as (Equation I):

$$
\operatorname{RCA}_{\mathrm{ij}}=\frac{\frac{\mathrm{X}_{\mathrm{ij}}}{\mathrm{X}_{\mathrm{it}}}}{\frac{\mathrm{X}_{\mathrm{wi}}}{\mathrm{X}_{\mathrm{wt}}}}
$$

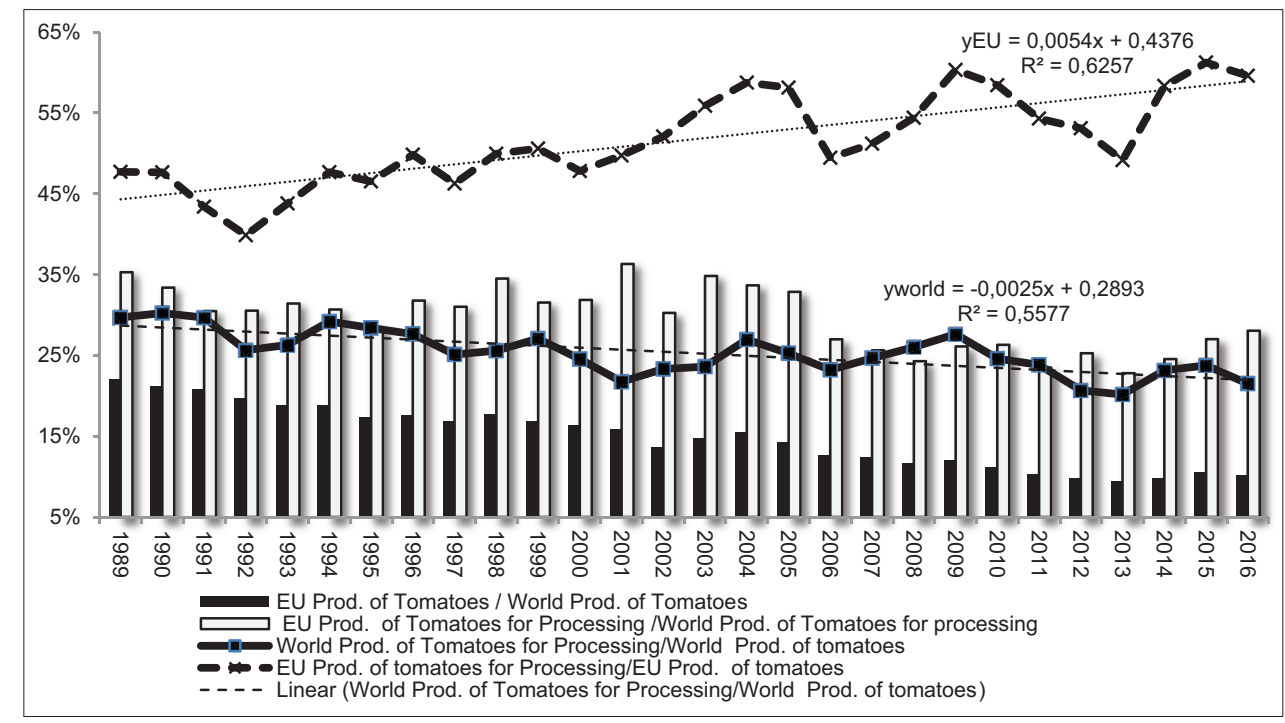

Fig 2. Relation between tomato production and tomato production for processing in the world and the European Union (by volume): 1989 to 2016. Source. FAOSTAT (several years) and WPTC (several years).

Table 2: Evolution of production in the Portuguese tomato industry

\begin{tabular}{|c|c|c|c|c|c|c|c|c|c|}
\hline Years & Prod $\left(n^{\circ}\right)$ & $\begin{array}{l}\text { Prod. } \\
\text { Org }\left(n^{\circ}\right)\end{array}$ & Area (ha) & $\begin{array}{c}\text { Prod. } \\
\text { Tomato (t) }\end{array}$ & Product (t/ha) & $\begin{array}{l}\text { Prod. } \\
\text { Final (t) }\end{array}$ & $\begin{array}{c}\text { Industrial } \\
\text { yield }\end{array}$ & $\begin{array}{c}\text { Price } \\
\text { Tomato }(€ / t)\end{array}$ & Aid $(€ / t)$ \\
\hline $1996-2000$ & $2,910.20$ & 36.00 & 14,968 & 898,136 & 60.92 & 166,555 & 5.41 & 91.19 & 224.63 \\
\hline 2004-2008 & 667.40 & 29.00 & 14,131 & $1,147,512$ & 81.25 & 182,447 & 6.29 & 78.61 & 30.54 \\
\hline $2012-2016$ & 448.00 & 18.80 & 16,610 & $1,424,621$ & 85.68 & 213,386 & 6.40 & - & 1.89 \\
\hline $\begin{array}{l}\text { Variation } \\
(1996 / 16)\end{array}$ & $-85 \%$ & $-48 \%$ & $11 \%$ & $59 \%$ & $41 \%$ & $28 \%$ & $18 \%$ & - & $-99 \%$ \\
\hline
\end{tabular}

Source: Elaborated by the authors, based on data from the Instituto Financiamento da Agricultura e Pescas (IFAP, 2017). 
Equation I represents the exports of country i for good $j$ and Xwj the world exports of good j; Xit are the exports of country $j$ and Xwt, are the world exports. If RCAij $>1$, it means that the country has specialized in the production of product $\mathrm{i}$ and has a comparative advantage in the product. If RCAij $<1$, the country is not specialized, and presents a comparative disadvantage.

The RCA Index has been criticized for its poor empirical distribution characteristics, as due to its asymmetric distribution, the output cannot be compared on both sides (Leromain and Orefice, 2013; Laursen, 1998). Numerous modifications have been suggested to overcome the empirical weakness of the RCA index. In order to overcome this weakness of the empirical distribution, Laursen (1998) and Dalum et al. (1998) elaborated the Revealed Symmetric Comparative Advantage (RSCA) (Equation II):

$$
R S C A_{i j}=\frac{R C A-1}{R C A+1}
$$

where RSCAij $>0$ means there is a comparative advantage and RSCAij $<0$ shows a comparative disadvantage for product $j$.

Competitiveness and intra-industry trade are linked and statistical tools must be employed to measure intra-industry trade. We use the Grubel-Lloyd indicator (GL) (Grubel and Lloyd, 1971; 1975) (Equation III):

$$
G L_{i j}=1-\frac{\left|X_{i j}-M_{i j}\right|}{X_{i j}+M_{i j}}
$$

where $\mathrm{Xij}$ is the exports of product $\mathrm{j}$ from country $\mathrm{i}$ and $\mathrm{Mij}$ is the imports of product $j$ from country $i$ (Latruffe, 2010). A $G L=0$ indicates that all trade is inter-industry (either exports or imports commodity j), while a $\mathrm{GL}=1$ indicates intra-industry trade only (the country simultaneously imports and exports within the same sector/industry).

Intra-industry trade (IT'T) corresponds to the simultaneous export and import of differentiated products belonging to the same industry, with it being necessary to distinguish between Horizontal Intra-Industry Trade (HIT) and Vertical Intra-Industry Trade (VIT). HIT refers to the exports and imports of goods from the same sector which differ in certain specific attributes but which are similar in quality. VIT goods are different in quality and, as a result, in price. Trade flows are defined as horizontally differentiated if the unit value difference is less than a given spread $(\alpha)$. Trade flows are defined as horizontally differentiated when $(\alpha)$ values in the unit value of exports in relation to the unit value of imports are lower than 15\% (Equation IV):

$$
(-) \leq \frac{P x_{i j}}{P m_{i j}} \leq(+)
$$

otherwise it is VIT: Pxij is the unit export price of good $\mathrm{i}$ for partner $j$ and Pmij, the unit price of product i of partner j (Greenaway, 1995; Amador and Cabral, 2009). We can consider this ratio as the terms of trade.

In order to identify the factors influencing tomato industry exports, we estimated a log-linear function of the CobbDouglas type log-linear demand (Shende and Bhole, 1999, Kumar and Rai, 2007, Kumar et al., 2008; Rani et al., 2014). The regression can be expressed as (Equation V):

$$
\begin{aligned}
& \ln \mathrm{Y}=\beta_{1}+\beta_{2} \ln Q_{p}+\beta_{3} \ln Q_{w}+\beta_{4} \ln M_{w} \\
& +\beta_{5} \ln P R_{w}+\beta_{6} \ln P R_{e u}+U_{i}
\end{aligned}
$$

where: $\mathrm{Y}=$ exports of tomato paste in volume of country $\mathrm{i}$; $\mathrm{Qp}=$ production of processing tomato for processing in volume of country $\mathrm{i}(\mathrm{Mt})$; $\mathrm{Qw}=$ world production of processing tomato for processing in volume; $\mathrm{Mw}=$ world imports of tomato paste in volume; $\mathrm{PRw}=$ ratio of export price of country $i$ and price and world export price; $P$ Reu $=$ ratio of export price of country $i$ and European Union export price; $\beta_{1}=$ Intercept $\beta_{\mathrm{i}}=$ elasticities, and $\mathrm{Ui}=$ random error terms.

We conducted the regression with all the parameters. We found large correlations between parameter estimates, and the model presented heteroscedasticity problems. Heteroscedasticity can be highly problematic with OLS methods. Coefficient $\beta$ i of the OLS model is the Best Linear Unbiased Estimator (BLUE) if the assumptions of the classic model, including homoscedasticity (Gujarati, 1995), are respected. The presence of heteroscedasticity did not result in biased parameter estimates. In the presence of heteroscedasticity, the OLS estimates were no longer BLUE. If homoscedasticity is untenable, we may be unable to rely on the interval estimates of the parameters, e.g., variance will no longer be so low; standard errors are biased and t-test and F-test are affected, resulting in inaccurate results. To avoid these problems, we dealt with heteroscedasticity by omitting the variable of processing tomato production of each country (Portugal and Spain). The final estimated regression was (Equation VI):

$$
\begin{aligned}
& \ln \mathrm{Y}=\beta_{1}+\beta_{2} \ln Q_{w}+\beta_{3} \ln M_{w}+ \\
& \beta_{4} \ln P R_{w}+\beta_{5} \ln P R_{e u}+U_{i}
\end{aligned}
$$

For the production of raw tomato for processing in quantity $(1,000 \mathrm{t})$, the database of the World Processing Tomato Council (WPTC, several years) was applied. For 
exports and imports of tomato paste (the values of exports and imports are expressed in 1,000 US\$) the FAOSTAT (several years) was applied. The unit prices are expressed in $1,000 \mathrm{US} \$ / \mathrm{t}$. We used the exports of tomato paste because this is the most significant product exported by Portugal and Spain. About $90 \%$ of tomato production is used to produce tomato paste. The regression was performed using the Least Squares Method (LSM) in the STATA Software (2007).

\section{RESULTS AND DISCUSSION}

To analyze the international competitiveness performance of Portuguese and Spanish processed tomato, the ratios of export competitiveness were estimated. Using net exports as an indicator of comparative advantage is been considered as more efficient than the structure of exports, since countries can be net exporters that use resources and economic assets they have to their provision and import goods that they also export (Ferranti et al., 2002). Export and import data issued by FAOSTAT (several years) were used. To build the RCA, RSCA and GL indicators, the average value of imports and exports of each product for each of the triennia between 1981 and 2013 was used (Table 3).

For Portugal, the results indicated that RCA for tomato products (all exports of tomato products) and for pasta were higher than one, showing the country has a comparative advantage. The RSCA for tomato paste is very close to one, which reveals a comparative advantage.
It is important to note that the values of the indicators decreased from 1981-83 to 2005-07 for tomato paste and for tomato products as a whole.

The last three-year period shows an improvement in international performance. The RCAs for peeled tomato and tomato juice are lower than one i.e., there is a comparative disadvantage. Spain has a comparative advantage for tomato pasta and for tomato products, but the indicators are lower than those of Portugal. As for juice, Spain presents a competitive advantage. Spain also shows better performance in peeled tomato.

For Portugal, the GL indicator is close to zero for tomato pasta, but close to one for the other products. This indicates an inter-industrial (net export) trade for tomato paste and intra-industry for peeled tomatoes and tomato juice. Table 3 shows that the terms of trade values varied during the period studied. For peeled tomato and tomato juice, the GL ratio indicates that the values are within the interval previously studied and it was considered an example of HIT.

For Spain, the trade in tomato paste and peeled tomato trade showed some overlap between exports and imports, but the value is lower than 0.5 and trade was considered as inter-industrial. In tomato juice, the indicator approaches one in several periods, which indicates HIT trade, i.e., the exported and imported goods present different attributes but similar quality.

Table 3: Competitiveness Indicators and Trade Terms, 1981-83 to 2011-13, for Portugal and Spain

\begin{tabular}{|c|c|c|c|c|c|c|c|c|c|c|c|c|}
\hline \multicolumn{7}{|c|}{ Portugal } & \multicolumn{6}{|c|}{ Spain } \\
\hline Years & 1981-83 & 1987-89 & 1993-95 & 1999-01 & $2005-07$ & 2011-13 & 1981-83 & 1987-89 & 1993-95 & 1999-01 & $2005-07$ & 2011-13 \\
\hline \multicolumn{13}{|c|}{ Tomato pasta } \\
\hline $\mathrm{RCA}$ & 41.56 & 25.25 & 20.93 & 17.30 & 17.35 & 20.18 & 4.56 & 3.98 & 4.71 & 3.86 & 5.49 & 4.54 \\
\hline RSCA & 0.95 & 0.92 & 0.91 & 0.89 & 0.89 & 0.91 & 0.64 & 0.60 & 0.65 & 0.59 & 0.69 & 0.64 \\
\hline GL index & 0.00 & 0.00 & 0.03 & 0.02 & 0.04 & 0.05 & 0.00 & 0.22 & 0.10 & 0.19 & 0.12 & 0.26 \\
\hline \multicolumn{13}{|c|}{ Peeled tomato } \\
\hline $\mathrm{RCA}$ & 0.34 & 0.31 & 0.50 & 0.86 & 0.70 & 3.09 & 6.81 & 5.18 & 3.29 & 2.41 & 3.02 & 4.11 \\
\hline RSCA & -0.49 & -0.53 & -0.33 & -0.08 & -0.18 & 0.52 & 0.74 & 0.68 & 0.53 & 0.41 & 0.50 & 0,61 \\
\hline GL index & 0.00 & 0.63 & 0.74 & 0.75 & 0.52 & 0.90 & 0.00 & 0.07 & 0.15 & 0.28 & 0.23 & 0.20 \\
\hline \multicolumn{13}{|c|}{ Tomato juice } \\
\hline $\mathrm{RCA}$ & 0.41 & 0.15 & 0.08 & 4.13 & 0.46 & 0.49 & 0.19 & 0.21 & 1.44 & 1.11 & 2.60 & 3.42 \\
\hline RSCA & -0.41 & -0.73 & -0.85 & 0.61 & -0.37 & -0.34 & -0.68 & -0.65 & 0.18 & 0.05 & 0.39 & 0.52 \\
\hline GL index & 0.00 & 0.87 & 0.47 & 0.23 & 0.76 & 0.84 & -0.05 & 0.65 & 0.56 & 0.84 & 0.57 & 0.33 \\
\hline \multicolumn{13}{|c|}{ All products } \\
\hline $\mathrm{RCA}$ & 29.99 & 16.75 & 14.06 & 12.14 & 12.12 & 14.74 & 5.75 & 4.29 & 4.27 & 3.28 & 4.85 & 4.51 \\
\hline RSCA & 0.94 & 0.89 & 0.87 & 0.85 & 0.85 & 0.87 & 0.70 & 0.62 & 0.53 & 0.53 & 0.66 & 0.64 \\
\hline GL index & 0.00 & 0.02 & 0.09 & 0.09 & 0.14 & 0.16 & 0.00 & 0.17 & 0.11 & 0.21 & 0.17 & 0.24 \\
\hline \multicolumn{13}{|c|}{ Trade terms } \\
\hline Pasta & & 0.54 & 1.05 & 1.04 & 0.90 & 1.03 & 0.24 & 1.45 & 1.86 & 1.58 & 1.24 & 1.54 \\
\hline Peeled & & 1.09 & 1.10 & 1.02 & 0.83 & 0.56 & 0.50 & 0.86 & 0.56 & 0.75 & 0.73 & 0.91 \\
\hline Juice & & & 1.65 & 0.50 & 1.20 & 2.61 & 0.49 & 0.93 & 0.62 & 1.02 & 1.37 & 0.65 \\
\hline
\end{tabular}

Source: Our own elaboration based on FAOSTAT (several years). 
Oliveira, et al.

Table 4: Demand model for tomato concentrate exports from Portugal and Spain (1989 to 2013)

\begin{tabular}{|c|c|c|c|c|c|c|c|c|}
\hline & \multicolumn{4}{|c|}{ Portugal } & \multicolumn{4}{|c|}{ Spain } \\
\hline & Coefficient & S.E. & t-ratio & $\mathrm{p}$-value & Coefficient & S.E. & t-ratio & $\mathrm{p}$-value \\
\hline$\beta 1$ & -0.811 & 1.605 & -0.51 & 0.619 & -0.578 & 1.961 & -0.29 & 0.771 \\
\hline$\beta 2$ & -0.050 & 0.235 & -0.21 & 0.833 & -0.015 & 0.229 & -0.07 & 0.949 \\
\hline$\beta 3$ & 0.847 & 0.135 & 6.28 & 0.000 & 0.770 & 0.156 & 4.93 & 0.000 \\
\hline$\beta 4$ & -2.140 & 0.670 & -3.19 & 0.005 & 0.761 & 0.608 & 1.25 & 0.225 \\
\hline \multirow[t]{2}{*}{$\beta 5$} & 1.023 & 0.613 & 1.67 & 0.111 & -2.478 & 0.650 & -3.81 & 0.001 \\
\hline & \multicolumn{4}{|c|}{$\begin{array}{c}R^{2}=0.9180 \text { Adj } R^{2}=0.9020 \\
F(4,20)=56 ; \text { Prob }>F=0.00 \text { Root MSE }=0.10\end{array}$} & \multicolumn{4}{|c|}{$\begin{array}{c}R^{2}=0.9832 \text { Adj } R^{2}=0.9798 \\
F(4,20)=292, \text { Prob }>F=0.00 \text { Root MSE }=0.10\end{array}$} \\
\hline
\end{tabular}

The results in Table 4 show that four factors can explain nearly $92 \%$ of the variation of Portuguese exports and $98 \%$ of Spanish exports of tomato paste. We observed that the coefficient of world imports of tomato concentrate in volume and the ratio of the export price of Portuguese concentrate and the world export price of tomato concentrate are statistically significant, 0.867 and -2.140 , respectively. This coefficient can be seen as output elasticity.

It was found that Portuguese exports increased, with a $1 \%$ increase in international trade leading, on average, to an increase of around $0.8 \%$ in Portuguese tomato paste exports. The relationship between Portuguese export prices and world prices is also an important variable in Portuguese exports, showing a negative effect: a $1 \%$ increase in this ratio led, on average, to a decrease of $2.14 \%$ in Portuguese exports. However, the coefficient of the ratio between Portuguese price and European price has a positive sign, but is not statistically different from zero.

For Spain, the coefficient of international imports was positive, statistically significant, and similar to Portugal's. Exports of Spanish tomato paste are influenced by the ratio between the Export Price and the European market price. This can mean that European price influences Spanish exports and the world price influences Portuguese exports. Competitiveness is typically fixed on price or cost competitiveness. The non-price component of farms and firms is seldom taken into consideration (Latruffe, 2010).

These differences might be motivated by the exposure of each market to the world market and to the European market. Between 2013 and 2015, exports of tomato paste from Spain represented about 298,758 thousand US\$ (triannual average values) and Portuguese exports represented 233,704 US\$ (tri-annual average values), i.e., Spain exported $28 \%$ more in exports value compared to Portugal. For Portugal, about $16 \%$ of exports were directed to the European Union market and 7\% to the world market. In Spain, about $21 \%$ of its exports in value were directed to the EU and 9\% to the world market. If we consider the differences in exports, it is possible to detect a greater exposure of Portugal to the world market when compared to Spain. If European imports are subtracted from world imports, Portugal accounts for $12 \%$ of world tomato paste imports and Spain represents 15\%. Considering that Spain exports more than Portugal, the Portuguese exposure to the world market is more apparent, which may help to understand the results obtained. In this context, quality is also an issue, since, according with Bunte and Roza (2007), Heinz prefers European production over American, as a result of the European GMO policy. The creation of a "European Designation-of-Origin could help Andalusia's industrial tomato production gain more strength globally" and the same time the Portuguese industry (Soares, 2019). The Origin Label can strengthen the competitiveness not only by costs competitiveness but namely by quality and diversification image (Tomato News, 2018).

\section{CONCLUSIONS}

The competitiveness of the Portuguese tomato industry declined over the study period, but in the 2011-2013 period, a slight improvement in the competitiveness indicator was revealed. Price is currently an important variable for the Portuguese and Spanish trade in tomato paste. Improving the differentiation of products and being less dependent on prices could improve the competitiveness of exports of processed tomato products. The international market for tomato products is competitive and dynamic. Innovation is a critical success factor. Emerging markets such as the traditional ones for Portuguese tomato products are demanding in terms of quality and good agricultural and environmental practices. Innovation in the food chain and the creation of value, not only at product level, but also in the efficient use of natural resources, should be strategic objectives.

Climate changes are also emerging, and this is a serious factor that should be a matter of concern for both countries. The production of raw tomato for processing depends significantly on weather conditions and, in some regions, on irrigation conditions. Portugal and Spain are simultaneously affected by strong droughts and unpredictable floods; seasonal climatic changes are now 
affecting not only the quantity but also the quality of raw materials. Over the last decade, greater cooperation has been observed between Portugal and Spain, in particular in the development of business groups that have grown from national to multinational firms. Working together could be a factor for development in both countries, generating synergies for research on new technologies to be applied not only in processing but also in production. This, in turn, could lead to the development of more environmentally friendly production techniques and improved adaptability of crops to the new environmental and legislative regulations implemented by the EU in its efforts towards environmentally and economically sustainable agriculture.

\section{Author's contributions}

The three authors (Dr. Oliveira, Dr. Suárez de Cepeda and Dr. Bernabéu) have jointly participated in writing all the sections in the article and have worked together on the search for information, statistical analysis, interpretation of the results, formulating the conclusions in conjunction and revising together the manuscript.

This article is the fruit of a multidisciplinary collaboration between two institutions; the Polytechnic Institute of Coimbra, Escola Superior Agrária Bencanta, 3045-601 Coimbra (Portugal) and the University of CastillaLa Mancha, Higher Technical School of Agricultural Engineering and Forestry, Campus Universitario s/n 02071 Albacete (Spain).

\section{REFERENCES}

Agência para o Investimento e Comércio Externo de Portugal. 2017. Several Years. Portuguese International Trade in Goods by Chapters of Combined. Portugal Livraria Digital. Available from: http://www.portugalglobal.pt/PT/Biblioteca/Paginas/Detalhe. aspx?documentld=01ddb0a3-31 ce-4459-8bbf-f0daf3022f93. [Last accessed on 2017 Feb 05].

Amador, J. and S. Cabral. 2009. O Comércio Intra-industrial na Economia Portuguesa: Produtos e Parceiros, Boletim Económico, Banco de Portugal. Verão, pp. 109-125.

Bunte, J. and P. Roza. 2007. Peeling Tomato Paste Subsidies: The Impact of a Revision of the CMO for Processing Tomatoes on European Horticulture Den Haag, LEI, Hague.

Dalum, B., K. Laursen and G. Villumsen. 1998. Structural change in OCDE export specialisation patterns: De-specialisation and "Stickiness". Int. Rev. Appl. Econ. 12: 447-467.

FAOSTAT. Several Years. DataBase Trade: Crops and Livestock Products. Available from: http://www.fao.org/faostat/en/\#data/ TP. [Last accessed on 2019 May 08].

Ferranti, D., G. Perry, D. Lederman and W. Maloney. 2002. From Natural Resources to the Knowledge Economy: Trade and Job Quality. World Bank Latin American and Caribbean Studies. World Bank. Available from: http://www.documents.worldbank. org/curated/en/563331468088167696/From-natural-resources- to-the-knowledge-economy-trade-and-job-quality.

Greenaway, D., R. Hine and C. R. Milner. 1995. Vertical and horizontal intra-industry trade: A cross-industry analysis for the United Kingdom. Econ. J. 105: 1505-1518.

Grubel, G. and P. J. Lloyd. 1971. The empirical measurement of intraindustry trade. Econ. Rec. 47(4): 494-517.

Grubel, H. G. and P. J. Lloyd. 1975. Intra-industry Trade: The Theory and Measurement of International Trade in Differentiated Products. Wiley, New York.

Gujarati, D. N. 1995. Basic Econometrics. $3^{\text {rd }}$ ed. McGraw-Hill International Ed. New York.

Instituto Financiamento da Agricultura e Pescas. 2017. Ajudas ao Setor do Tomate Campanhas 1996/1997 a 2016. Available from: https://www.ifap.pt/estatisticas-setor-do-tomate. [Last accessed on 2017 Feb 05].

Instituto Nacional de Estadística (INE). 2016. Agricultural Statistics 2015. Instituto Nacional de Estadística, Portugal.

Kumar, N. and M. Rai. 2007. Performance, competitiveness and determinants of tomato export from India. Agric. Econ. Res. Rev. 20: 551-562.

Kumar, N., A. Rai and M. Rai. 2008. Export of cucumber and gherkin from India: Performance. Agric. Econ. Res. Rev. 21: 130-138.

Latruffe, L. 2010. Competitiveness, Productivity and Efficiency in the Agricultural and Agri-Food Sectors. OECD Food, Agriculture and Fisheries Papers, No. 30.

Laursen, K. 1998. Revealed Comparative Advantage and the Alternatives as Measures of International Specialization. DRUID, Working Paper, pp. 98-30.

Leromain, E. and G. Orefice. 2013. New Revealed Comparative Advantage Index: Dataset and Empirical Distribution. Centre D'Études Prospectives et D'Informations Internationales, Paris. Document de Travail No. 20.

Llerena, J. L. 2015. El Tomate Para Industria. Available from: http://www.unex.es/conoce-la-uex/centros/eia/archivos/ iag/2014/2014_07 El tomate para industria.pdf. [Last accessed on 2019 May 08].

Oliveira, M. F. 2006. The evolution of the Portuguese processed tomato sector: Situation and prospects on the global market. New Medit. 5(1): 38-46.

Rani, P., S. Immanuel and R. Kumar. 2014. Ornamental fish exports from India: Performance, competitiveness and determinants. Int. J. Fish. Aquat. Stud. 1(4): 85-92.

Shende N. and B. Bhole. 1999. Export potential for India's food grains. Econ. Aff. Calcutta. 44(1): 59-64.

Soares, D. 2019. Seville has been a Great Bet for the Sugal Group, Specialized in Tomato Processing. Available from: http://www. tomatonews.com/en/the-future-of-processing-tomato-is-in-aeuropean-label-not-local_2_731.html.

STATA Software. 2007. Statistisc Data Analysis. Versión 10.0. StataCorp, Texas, USA.

Tomato News. 2018. The World's TOP40 Biggest Processing Companies. Available from: http://www.tomatonews.com/en/theworlds-top40-biggest-processing-companies_2_355.html.

Tomato News. 2014. Dossier Italy: The Main Global Exporter of Tomato Products. Global Consumption Survey 2012/2013, pp. 35-56.

World Processing Tomato Council (WPTC). Several Years. World Production Estimate of Tomatoes for Processing. [Last accessed on 2019 May 08]. 